\title{
Lyme disease: the next decade
}

This article was published in the following Dove Press journal:

Infection and Drug Resistance

6 January 2011

Number of times this article has been viewed

\section{Raphael B Stricker \\ Lorraine Johnson}

International Lyme and Associated Diseases Society, Bethesda, MD, USA

Correspondence: Raphael B Stricker

450 Sutter Street, Suite I504,

San Francisco, CA 94108, USA

$\mathrm{Tel}+\mathrm{I}(415)$ 399-1035

Fax +I (4I5) 399-1057

Email rstricker@usmamed.com
Abstract: Although Lyme disease remains a controversial illness, recent events have created an unprecedented opportunity to make progress against this serious tick-borne infection. Evidence presented during the legally mandated review of the restrictive Lyme guidelines of the Infectious Diseases Society of America (IDSA) has confirmed the potential for persistent infection with the Lyme spirochete, Borrelia burgdorferi, as well as the complicating role of tick-borne coinfections such as Babesia, Anaplasma, Ehrlichia, and Bartonella species associated with failure of short-course antibiotic therapy. Furthermore, renewed interest in the role of cell wall-deficient (CWD) forms in chronic bacterial infection and progress in understanding the molecular mechanisms of biofilms has focused attention on these processes in chronic Lyme disease. Recognition of the importance of CWD forms and biofilms in persistent $B$. burgdorferi infection should stimulate pharmaceutical research into new antimicrobial agents that target these mechanisms of chronic infection with the Lyme spirochete. Concurrent clinical implementation of proteomic screening offers a chance to correct significant deficiencies in Lyme testing. Advances in these areas have the potential to revolutionize the diagnosis and treatment of Lyme disease in the coming decade.

Keywords: Lyme disease, Borrelia burgdorferi, L-forms, cysts, biofilms, proteomics

\section{The gathering storm}

Lyme disease is a controversial illness. ${ }^{1,2}$ Over the past decade, two opposing camps have emerged in the controversy over this tick-borne illness. One camp is represented by the Infectious Diseases Society of America (IDSA), which maintains that Lyme disease is a rare illness localized to well-defined areas of the world. ${ }^{3,4}$ According to IDSA, the disease is 'hard to catch and easy to cure' because the infection is rarely encountered, easily diagnosed in its early stage by means of accurate commercial laboratory tests, and effectively treated with a short course of antibiotics over 2 to 4 weeks. Chronic infection with the Lyme spirochete, Borrelia burgdorferi, is rare or nonexistent. ${ }^{3,4}$

The opposing camp is represented by the International Lyme and Associated Diseases Society (ILADS), which argues that Lyme disease is not rare and, because its spread is facilitated by rodents, deer, and birds, can be found in an unpredictable distribution around the world accompanied by other tick-borne coinfections that may complicate the clinical picture. According to ILADS, tickbites often go unnoticed and commercial laboratory testing for Lyme disease is inaccurate..${ }^{1,5}$ Consequently the disease is often not recognized and may persist in a large number of patients who are untreated or undertreated, requiring prolonged antibiotic therapy to eradicate persistent infection with the evasive Lyme spirochete. ${ }^{1,5}$ submit your manuscript | www.dovepress.com

Dovepress

DOI: $10.2147 /$ IDR.S1 5653
Infection and Drug Resistance 201 I:4 I-9

(C) 201 I Stricker and Johnson, publisher and licensee Dove Medical Press Ltd. This is an Open Access article which permits unrestricted noncommercial use, provided the original work is properly cited. 
The controversy over Lyme disease came to a head in November 2006 when IDSA released new guidelines severely limiting treatment options for patients with persistent Lyme symptoms. ${ }^{3}$ The guidelines were so restrictive that the Attorney General of Connecticut initiated an unprecedented investigation into potential antitrust violations by IDSA, the dominant infectious disease society in the United States, in its formulation of the guidelines. ${ }^{6-8}$ The investigation found significant conflicts of interest and suppression of data in the guidelines development process. ${ }^{6,7}$ As a result, IDSA created a new scientific panel to review its Lyme guidelines in a process under the complete control of IDSA. ${ }^{8,9}$ The review panel held a hearing in July 2009 that was broadcast live over the internet and featured more than 300 peer-reviewed articles and 1600 pages of analysis supporting the concept of persistent infection despite short-course antibiotic therapy of 2 to 4 weeks in patients with persistent Lyme disease symptoms. ${ }^{8,9}$ Despite this extensive evidence, the IDSA review panel voted unanimously to uphold the flawed Lyme guidelines. This result was not surprising given that seven of the eight members of the review panel were members of IDSA, which selected the panel..$^{8,9}$

\section{Advances and contradictions}

The unprecedented legal action against the IDSA Lyme guidelines reflected frustration over the widening gap between groundbreaking experimental evidence and entrenched clinical practices in Lyme disease. ${ }^{8,9}$ The past decade witnessed significant advances in understanding the pathogenesis of B. burgdorferi infection. ${ }^{10-16}$ The genome of $B$. burgdorferi was sequenced in its entirety, and the biologic and immunologic contribution of various genes was elucidated. ${ }^{10-12}$ In particular, the mechanisms of "stealth pathology" utilized by the Lyme spirochete in evading the host immune response and establishing infection in diverse tissues was illuminated. ${ }^{13-16}$ Animal models of Lyme disease in gerbils, hamsters, mice, dogs, monkeys, and horses provided evidence for persistent infection in various tissues following experimental transmission of B. burgdorferi..$^{17-30}$ In many of these models, infection persisted despite the equivalent of short-course antibiotic therapy. ${ }^{19-27}$

While progress was being made in research models of tickborne disease, controversy raged over the clinical features of Lyme disease. ${ }^{31-41}$ A growing number of studies highlighted persistent symptoms in patients following clinical infection with B. burgdorferi, but the pathologic mechanism of those symptoms remained murky. ${ }^{31-36}$ The concepts of 'post-Lyme syndrome', 'post-treatment Lyme disease', and 'chronic
Lyme disease' were hotly debated, and the issues of postinfectious autoimmunity versus persistent spirochetal infection remained unsettled despite numerous studies from Europe and the United States that documented failure of short-course antibiotic therapy and persistent $B$. burgdorferi infection in various tissues (Appendix 1). ${ }^{33-36}$ The role of prolonged antibiotic therapy in patients with persistent Lyme symptoms was also debated based on conflicting study results involving a limited number of patients who had been symptomatic for long periods and had already failed similar treatment. ${ }^{42-47}$ The generalizability of these studies to the majority of patients with persistent Lyme symptoms was also questioned. ${ }^{47}$

\section{Evidence for chronic infection}

The comprehensive review of the IDSA Lyme guidelines provided strong evidence for chronic spirochetal infection in patients with persistent Lyme symptoms (Appendix 1). ${ }^{48-58}$ This evidence was supported by ongoing studies showing failure of 'standard' antibiotic therapy in mice infected with the Lyme spirochete. ${ }^{20-24}$ Coupled with previous animal and human studies of persistent infection and antibiotic failure, this evidence underscores the importance of chronic infection in Lyme disease. It also raises many questions about the mechanism(s) and optimum therapy for persistent spirochetal illness.

Complementing the evidence in favor of chronic B. burgdorferi infection, clinical and experimental studies have shown that tick-borne coinfections may also have chronic phases. ${ }^{59-67}$ In the past, reports of pathology due to Babesia, Anaplasma, Ehrlichia, and Bartonella species have focused on the fulminant acute forms of infection that are relatively easy to diagnose and often fatal in immunocompromised patients. ${ }^{61,63,67}$ More recently, these organisms have been associated with chronic persistent infection in animal models and humans. ${ }^{59-67}$ The presence of coinfecting organisms has been shown to enhance the symptoms and exacerbate the severity of Lyme disease ${ }^{68-73}$ Thus recognition of chronic coinfections supports the concept of unresolved illness due to persistent infection with the Lyme spirochete.

\section{Renewed interest in cell wall deficient bacterial forms}

Cell wall-deficient (CWD) bacterial forms were first described in 1935 by Klieneberger, who named them L-forms after the Lister Institute where she worked. ${ }^{74}$ Subsequent research by Dienes showed that various bacteria could form CWD colonies and then revert back to bacillary morphology under appropriate conditions. ${ }^{75}$ An extensive review by Domingue 
and Woody highlighted the extent of CWD morphology in many bacterial strains and the potential role of these mutant bacteria to produce persistent infection and chronic diseases. ${ }^{76}$ The confusing terminology used to describe CWD bacteria has hindered work in this field. While the term 'L-form' or 'spheroplast' describes CWD morphology in coccobacillary organisms, the term 'cyst' or 'round body' has been used to describe similar morphology in spirochetes. ${ }^{76}$

Margulis et al described CWD spirochetal forms in $1993 .^{77}$ Subsequently Preac-Mursic and colleagues demonstrated the formation and cultivation of $B$. burgdorferi 'spheroplastL-form variants', ${ }^{78}$ and Brorson et al showed that these forms, which he termed cysts or round bodies, could revert to viable spiral forms of the bacteria. ${ }^{79,80}$ This observation has been confirmed by other investigators. ${ }^{81-83}$ Although the pathogenicity of CWD borrelial forms has been questioned, ${ }^{3}$ recent studies have suggested a link between CWD borrelia and neurodegenerative diseases, ${ }^{84-86}$ and resistance of cystic forms to antibiotic therapy has been documented ${ }^{87-90}$ Recent advances in understanding molecular mechanisms of CWD bacterial formation has offered a glimpse at new treatment approaches to chronic Lyme disease. ${ }^{90}$ Currently the only antibiotic that reliably targets the cyst form of B. burgdorferi is metronidazole or its derivatives, ${ }^{87,88}$ while other agents have yielded negative or conflicting treatment results with cysts. ${ }^{23,89,90}$ Given the potential importance of CWD forms in persistent $B$. burgdorferi infection, newer antibiotics aimed at this evasive mutant are desperately needed to eradicate chronic infection in Lyme disease. ${ }^{85}$

\section{Biofilms}

Another mechanism of chronic infection involves the formation of biofilms. ${ }^{92-98}$ These adherent polysaccharide-based matrices protect bacteria from the hostile host environment and facilitate persistent infection. Biofilms are responsible for a number of chronic infections, including periodontitis, chronic otitis media, endocarditis, gastrointestinal infection, and chronic lung infection. ${ }^{92-98}$ Sapi and MacDonald raised the possibility of biofilm formation by B. burgdorferi, and subsequent work has demonstrated these spirochetal formations in culture and in the tick gut. ${ }^{99,100}$ Combinations of borrelial cysts and putative biofilms have also been noted in patient skin biopsies using focus floating microscopy. ${ }^{101}$ Biofilm formation is dependent on cyclic di-GMP expression, ${ }^{102,103}$ and recent studies have shown that $B$. burgdorferi expresses this regulatory molecule. ${ }^{104,105}$ Coordinated steps in the elaboration of biofilms have been demonstrated in other bacteria, and it remains to be seen whether similar molecular processes occur in borrelial strains and whether these processes play a role in persistent infection. ${ }^{106,107}$

To date no antibiotic treatment exists for biofilm formation. However elucidation of the regulatory steps in the biofilm process should allow development of 'designer' antibiotics that interfere with this process. ${ }^{106}$ It has recently been shown that mutations in genes that regulate biofilm development can interfere with the elaboration of new biofilms and also cause collapse of established biofilm colonies. ${ }^{107}$ These findings indicate the potential effectiveness of newer antibiotics that target the biofilm regulatory process, suggesting a novel approach to treatment of Lyme disease and other chronic infections. ${ }^{108,109}$

\section{Testing for Lyme disease}

As we enter a new decade, clinical testing for Lyme disease remains abysmal. ${ }^{110-115}$ The two-tier algorithm recommended by the Centers for Disease Control and Prevention utilizes a screening enzyme-linked immunosorbent assay (ELISA) or immunofluorescence assay followed by a confirmatory Western blot. Although this approach has a high test specificity, the sensitivity of the two-tier approach in Lyme disease patients tested at least 4 to 6 weeks after infection is only $44 \%$ to $56 \%$, which is inadequate for a clinical diagnostic test and, by comparison, far below the $99.5 \%$ sensitivity of diagnostic HIV testing. ${ }^{110,114,115}$ Furthermore, the misconception that two-tier testing is highly sensitive for Lyme disease patients with persistent arthritic or neurologic symptoms derives from a study that selected patients based on positive Lyme testing and then showed high levels of two-tier test positivity. ${ }^{115}$ This circular reasoning is a systematic problem with the evaluation of Lyme testing.

There are a number of reasons for the inaccuracy of Lyme testing, including use of less antigenic laboratory spirochetal strains in the commercial test kits, elimination of important spirochetal target proteins from those kits, and lack of standardization of the commercial Lyme assays. ${ }^{111-113}$ Gender bias may also be a factor: while chronic Lyme disease is reportedly more common in women, the two-tier test system yields positive results more often in men. ${ }^{116}$ Although a newer ELISA targeting the conserved V1sE or C6 peptide of B. burgdorferi has been developed, this test system does not appear to be more sensitive than the two-tier approach. ${ }^{17,118}$ While molecular testing has been useful for diagnostic confirmation and treatment monitoring in other illnesses, molecular testing for B. burgdorferi has been unreliable, and newer molecular techniques targeting tick-borne agents remain unproven and expensive. ${ }^{19,120}$ Assays for more accessible 
surrogate markers of Lyme disease have yet to be accepted by the general medical community. ${ }^{121-125}$ Thus testing for Lyme disease remains problematic.

A newer approach to Lyme testing involves the use of proteomics. ${ }^{126,127}$ Based on the known genetic make-up of the spirochete, numerous proteins can be generated in vitro and tested for antigenicity using Lyme patient sera. In this manner, novel target proteins can be identified, and conceivably new test systems based on these proteins can be developed without even knowing the function or location of the antigens within the spirochete. ${ }^{126}$ Work on these proteomic-based test systems is already in progress, but extensive clinical validation will be required to bring those tests to market. Nevertheless the proteomic approach to Lyme testing holds great promise for more accurate serological diagnosis, and development of proteomic testing for tick-borne diseases provides a useful diagnostic model for other chronic and elusive infections. Beyond proteomics, novel test systems that exploit electromagnetic signals generated by bacterial DNA sequences may also prove to be effective in the diagnosis of chronic Lyme disease. ${ }^{128,129}$

\section{Big pharma is watching}

Until now, the pharmaceutical industry has steered clear of Lyme disease. There are a number of reasons for this avoidance, including the fear of entry into a controversial field and the perception that Lyme disease is easy to treat with short-course generic antibiotics. In simple terms, uncertainty about the disease and lack of profitable treatment options has limited pharmaceutical involvement in Lyme disease. This scenario is in stark contrast to the AIDS epidemic, where the prospect of billion-dollar antiviral sales propelled the pharmaceutical industry into a leading role in combating the pandemic. ${ }^{130,131}$ In a more recent example, the development of effective (and lucrative) drug therapy for fibromyalgia has boosted the status of that previously maligned diagnostic entity and fostered unprecedented awareness of the condition in the medical community and among the lay public. ${ }^{132}$ The lack of a similar dynamic in Lyme disease has been a significant roadblock to progress in treating the tick-borne illness.

Progress in understanding the various aspects of Lyme disease outlined above should encourage the pharmaceutical industry to assume a more active role in the Lyme arena. The evidence for chronic infection with the Lyme spirochete and coinfecting organisms supports a greater need for antibiotic therapy in this disease beyond the 2 to 4 weeks specified in the discredited IDSA guidelines. ${ }^{133,134}$ The need for more effective treatment of this chronic infection in turn supports the use of more complex (and lucrative) antibiotic regimens in Lyme disease. In a similar vein, targeting CWD forms of $B$. burgdorferi and biofilm formation offers the prospect of new antibiotic approaches to the disease, with an exciting opportunity for innovative therapeutics and increased profits. Development of antibiotic agents that target spirochetal CWD forms and biofilms may also provide valuable insight into the treatment of other chronic infections. The development of more reliable testing for Lyme disease based on proteomics will help to define the population in need of these innovative therapies. More reliable standardized testing will also assure reimbursement for newer Lyme therapies from third party payors.

\section{Conclusions}

In summary, extensive evidence now shows that persistent symptoms of Lyme disease are due to chronic infection with the Lyme spirochete in conjunction with other tick-borne coinfections. The mechanisms of chronic infection appear to involve CWD forms of the spirochete and biofilm formation, and these infectious processes are attractive targets for future drug development. Institution of more reliable Lyme testing based on proteomics should dispel uncertainty over the presence of the disease and facilitate targeting of patients who require treatment. The opportunity for the pharmaceutical industry to develop new drugs targeting novel infectious processes in a well-defined patient population will lead to broader recognition and more effective treatment of Lyme disease over the next decade.

\section{Acknowledgments}

The authors thank Drs Stephen Barthold, Robert Bransfield, Joseph Burrascano, Daniel Cameron, Allison DeLong, Brian Fallon, Chris Green, Nick Harris, Steven Harris, Robert Lane, Kenneth Liegner, Benjamin Luft, Alan MacDonald, Betty Maloney, David Martz, Carsten Nicolaus, Steven Phillips, Eva Sapi, Ginger Savely, Armin Schwarzbach, David Volkman, Edward Winger, and Ying Zhang for helpful discussion. We also thank Pam Weintraub and Kris Newby for their insight, and we are grateful to Pat Smith of the Lyme Disease Association, Diane Blanchard and Deb Siciliano of Time for Lyme, Staci Grodin of Turn the Corner Foundation, and Barb Barsocchini, Dorothy Leland, and Phyllis Mervine of the California Lyme Disease Association for continuing support. There was no funding source for this article. Ethical approval was not required for this article. 


\section{Disclosure}

RBS serves without compensation on the medical advisory panel for QMedRx Inc. He has no financial ties to the company. LJ has no potential conflicts of interest to declare.

\section{References}

1. Stricker RB, Lautin A, Burrascano JJ. Lyme disease: point/counterpoint. Expert Rev Anti-Infect Ther. 2005;3:155-165.

2. Harvey WT, Salvato P. 'Lyme disease': ancient engine of an unrecognized borreliosis pandemic? Med Hypotheses. 2003;60:742-759.

3. Wormser GP, Dattwyler RJ, Shapiro ED, et al. The clinical assessment, treatment, and prevention of lyme disease, human granulocytic anaplasmosis, and babesiosis: clinical practice guidelines by the Infectious Diseases Society of America. Clin Infect Dis. 2006;43:1089-1134.

4. IDSA Website. Frequently asked questions about Lyme disease. Available from: http://www.idsociety.org/lymediseasefacts.htm. Accessed Nov 82010.

5. Cameron D, Gaito A, Harris N, et al. Evidence-based guidelines for the management of Lyme disease. Expert Rev Anti Infect Ther. 2004; 2(Suppl 1):S1-S13.

6. Connecticut Attorney General's Office. Attorney General's investigation reveals flawed Lyme disease guideline process, IDSA agrees to reassess guidelines, install independent arbiter. 2008 May 1. Available from: http://www.ct.gov/ag/cwp/view.asp?a=2795\&q=414284. Accessed Nov 82010.

7. Stricker RB, Johnson L. The Infectious Diseases Society of America Lyme guidelines: poster child for guidelines reform. South Med J. 2009; 102:565-566.

8. Johnson L, Stricker RB. The Infectious Diseases Society of America Lyme guidelines: a cautionary tale about development of clinical practice guidelines. Philos Ethics Humanit Med. 2010;5:9.

9. Johnson L, Stricker RB. Final report of the Lyme Disease Review Panel of the Infectious Diseases Society of America: A pyrrhic victory? Clin Infect Dis. 2010;51:1108-1109.

10. Casjens S, Palmer N, van Vugt R, et al. A bacterial genome in flux: the twelve linear and nine circular extrachromosomal DNAs in an infectious isolate of the Lyme disease spirochete Borrelia burgdorferi. Mol Microbiol. 2000;35:490-516.

11. Von Lackum K, Babb K, Riley SP, Wattier RL, Bykowski T, Stevenson B. Functionality of Borrelia burgdorferi LuxS: the Lyme disease spirochete produces and responds to the pheromone autoinducer-2 and lacks a complete activated-methyl cycle. Int J Med Microbiol. 2006; 296(Suppl 40):92-102.

12. Bulut Y, Faure E, Thomas L, Equils O, Arditi M. Cooperation of Tolllike receptor 2 and 6 for cellular activation by soluble tuberculosis factor and Borrelia burgdorferi outer surface protein A lipoprotein: role of Toll-interacting protein and IL-1 receptor signaling molecules in Toll-like receptor 2 signaling. J Immunol. 2001;167:987-994.

13. Embers ME, Ramamoorthy R, Philipp MT. Survival strategies of Borrelia burgdorferi, the etiologic agent of Lyme disease. Microbes Infect. 2004;6:312-318.

14. Skotarczak B. Adaptation factors of Borrelia for host and vector. Ann Agric Environ Med. 2009;16:1-8.

15. Cruz AR, Moore MW, La Vake CJ, Eggers CH, Salazar JC, Radolf JD. Phagocytosis of Borrelia burgdorferi, the Lyme disease spirochete, potentiates innate immune activation and induces apoptosis in human monocytes. Infect Immun. 2008;76:56-70.

16. Pietikainen J, Meri T, Blom AM, Meri S. Binding of the complement inhibitor C4b-binding protein to Lyme disease Borreliae. Mol Immunol. 2010;47:1299-1305.

17. Lovrich SD, Callister SM, Schmitz JL, Alder JD, Schell RF. Borreliacidal activity of sera from hamsters infected with the Lyme disease spirochete. Infect Immun. 1991;59:2522-2528.
18. Montgomery RR, Nathanson MH, Malawista SE. The fate of Borrelia burgdorferi, the agent for Lyme disease, in mouse macrophages. Destruction, survival, recovery. J Immunol. 1993;150:909-915.

19. Malawista SE, Barthold SW, Persing DH. Fate of Borrelia burgdorferi DNA in tissues of infected mice after antibiotic treatment. J Infect Dis. 1994;170:1312-1316.

20. Bockenstedt LK, Mao J, Hodzic E, Barthold SW, Fish D. Detection of attenuated, noninfectious spirochetes in Borrelia burgdorferi-infected mice after antibiotic treatment. J Infect Dis. 2002;186:1430-1437.

21. Yrjänäinen H, Hytönen J, Song XY, Oksi J, Hartiala K, Viljanen MK. Anti-tumor necrosis factor-alpha treatment activates Borrelia burgdorferi spirochetes 4 weeks after ceftriaxone treatment in $\mathrm{C} 3 \mathrm{H} / \mathrm{He}$ mice. $J$ Infect Dis. 2007;195:1489-1496.

22. Hodzic E, Feng S, Holden K, Freet KJ, Barthold SW. Persistence of Borrelia burgdorferi following antibiotic treatment in mice. Antimicrob Agents Chemother. 2008;52:1728-1736.

23. Barthold SW, Hodzic E, Imai DM, Feng S, Yang X, Luft BJ. Ineffectiveness of tigecycline against persistent Borrelia burgdorferi. Antimicrob Agents Chemother. 2010;54:643-6451.

24. Yrjänäinen H, Hytönen J, Hartiala P, Oksi J, Viljanen MK. Persistence of borrelial DNA in the joints of Borrelia burgdorferi-infected mice after ceftriaxone treatment. APMIS. 2010;118:665-6673.

25. Straubinger RK, Summers BA, Chang YF, Appel MJ. Persistence of Borrelia burgdorferi in experimentally infected dogs after antibiotic treatment. J Clin Microbiol. 1997;35:111-116.

26. Straubinger RK. PCR-based quantification of Borrelia burgdorferi organisms in canine tissues over a 500-day postinfection period. J Clin Microbiol. 2000;38:2191-2199.

27. Chang YF, Ku YW, Chang CF, et al. Antibiotic treatment of experimentally Borrelia burgdorferi-infected ponies. Vet Microbiol. 2005;107: 285-294.

28. Preac-Mursic V, Patsouris E, Wilske B, Reinhardt S, Gross B, Mehraein P. Persistence of Borrelia burgdorferi and histopathological alterations in experimentally infected animals. A comparison with histopathological findings in human Lyme disease. Infection. 1990;18: $332-341$.

29. Cadavid D, Bai Y, Hodzic E, Narayan K, Barthold SW, Pachner AR. Cardiac involvement in non-human primates infected with the Lyme disease spirochete Borrelia burgdorferi. Lab Invest. 2004;84: $1439-1450$.

30. Miller JC, Narayan K, Stevenson B, Pachner AR. Expression of Borrelia burgdorferi erp genes during infection of non-human primates. Microb Pathog. 2005;39:27-33.

31. Phillips SE, Harris NS, Horowitz R, Johnson L, Stricker RB. Lyme disease: scratching the surface. Lancet. 2005;366:1771.

32. Phillips SE, Burrascano JJ, Harris NS, Johnson L, Smith PV, Stricker RB. Chronic infection in 'post-Lyme borreliosis syndrome'. Int J Epidemiol. 2005;34:1439-1440.

33. Steere AC, Falk B, Drouin EE, Baxter-Lowe LA, Hammer J, Nepom GT. Binding of outer surface protein $A$ and human lymphocyte functionassociated antigen 1 peptides to HLA-DR molecules associated with antibiotic treatment-resistant Lyme arthritis. Arthritis Rheum. 2003;48:534-540.

34. Kalish RS, Wood JA, Golde W, et al. Human T lymphocyte response to Borrelia burgdorferi infection: no correlation between human leukocyte function antigen type 1 peptide response and clinical status. J Infect Dis. 2003;187:102-108.

35. Stricker RB, Johnson L. Searching for autoimmunity in "antibioticrefractory" Lyme arthritis. Mol Immunol. 2008;45:3023-3024.

36. Johnson L, Stricker RB. Treatment of Lyme disease: a medicolegal assessment. Expert Rev Anti Infect Ther. 2004;2:533-557.

37. Radolf J. Posttreatment chronic Lyme disease - what it is not. $J$ Infect Dis. 2005;192:948-949.

38. Sigal LH, Hassett AL. Contributions of societal and geographical environments to 'chronic Lyme disease': the psychopathogenesis and aporology of a new 'medically unexplained symptoms' syndrome. Environ Health Perspect. 2002;110(Suppl 4):607-611. 
39. Feder HM Jr, Johnson BJ, O’Connell S, Shapiro ED, Steere AC, Wormser GP. Ad Hoc International Lyme Disease Group. A critical appraisal of 'chronic Lyme disease'. $N$ Engl J Med. 2007;357: 1422-1430.

40. Keilp JG, Corbera K, Slavov I, Taylor MJ, Sackeim HA, Fallon BA. WAIS-III and WMS-III performance in chronic Lyme disease. $J$ Int Neuropsychol Soc. 2006;12:119-129.

41. McAuliffe P, Brassard MR, Fallon B. Memory and executive functions in adolescents with posttreatment Lyme disease. Appl Neuropsychol. 2008; 15:208-219.

42. Klempner MS, Hu LT, Evans J, et al. Two controlled trials of antibiotic treatment in patients with persistent symptoms and a history of Lyme disease. N Engl J Med. 2001;345:85-92.

43. Krupp LB, Hyman LG, Grimson R, et al. Study and treatment of post Lyme disease (STOP-LD): a randomized double masked clinical trial. Neurology. 2003;60:1923-1930.

44. Fallon BA, Keilp JG, Corbera KM, et al. A randomized, placebocontrolled trial of repeated IV antibiotic therapy for Lyme encephalopathy. Neurology. 2008;70:992-1003.

45. Cameron D. Severity of Lyme disease with persistent symptoms: insights from a double blind placebo controlled clinical trial. Minerva Med. 2008;99:489-496.

46. Cameron DJ. Consequences of treatment delay in Lyme disease. J Eval Clin Pract. 2007;13:470-472.

47. Cameron DJ. Generalizability in two clinical trials of Lyme disease. Epidemiol Perspect Innov. 2006;3:12-18.

48. Preac-Mursic V, Weber K, Pfister HW, et al. Survival of Borrelia burgdorferi in antibiotically treated patients with Lyme borreliosis. Infection. 1989;17:355-359.

49. MacDonald AB, Berger BW, Schwan TG. Clinical implications of delayed growth of the Lyme borreliosis spirochete, Borrelia burgdorferi. Acta Trop. 1990;48:89-94.

50. Liegner KB, Shapiro JR, Ramsay D, Halperin AJ, Hogrefe W, Kong L. Recurrent erythema migrans despite extended antibiotic treatment with minocycline in a patient with persisting Borrelia burgdorferi infection. J Am Acad Dermatol. 1993;28(2 pt 2):312-314.

51. Preac-Mursic V, Pfister HW, Spiegel H, et al. First isolation of Borrelia burgdorferi from an iris biopsy. J Clin Neuroophthalmol. 1993;13: 155-161.

52. Battafarano DF, Combs JA, Enzenauer RJ, Fitzpatrick JE. Chronic septic arthritis caused by Borrelia burgdorferi. Clin Orthop Relat Res. 1993;297:238-241.

53. Nocton JJ, Dressler F, Rutledge BJ, Rys PN, Persing DH, Steere AC. Detection of Borrelia burgdorferi DNA by polymerase chain reaction in synovial fluid from patients with Lyme arthritis. $N$ Engl J Med. 1994;330:229-234.

54. Bayer ME, Zhang L, Bayer MH. Borrelia burgdorferi DNA in the urine of treated patients with chronic Lyme disease symptoms: a PCR study of 97 cases. Infection. 1996;24:347-353.

55. Nocton JJ, Bloom BJ, Rutledge BJ, et al. Detection of Borrelia burgdorferi DNA by polymerase chain reaction in cerebrospinal fluid in Lyme neuroborreliosis. J Infect Dis. 1996;174:623-627.

56. Frey M, Jaulhac B, Piemont Y, et al. Detection of Borrelia burgdorferi DNA in muscle of patients with chronic myalgia related to Lyme disease. Am J Med. 1998;104:591-594.

57. Oksi J, Marjamäki M, Nikoskelainen J, Viljanen MK. Borrelia burgdorferi detected by culture and PCR in clinical relapse of disseminated Lyme borreliosis. Ann Med. 1999;31:225-232.

58. Breier F, Khanakah G, Stanek G, et al. Isolation and polymerase chain reaction typing of Borrelia afzelii from a skin lesion in a seronegative patient with generalized ulcerating bullous lichen sclerosus et atrophicus. Br J Dermatol. 2001;144:387-392.

59. Krause PJ, Spielman A, Telford SR, et al. Persistent parasitemia after acute babesiosis. N Engl J Med. 1998;339:160-165.

60. Allred DR. Babesiosis: persistence in the face of adversity. Trends Parasitol. 2003;19:51-55.
61. Vannier E, Gewurz BE, Krause PJ. Human babesiosis. Infect Dis Clin North Am. 2008;22:469-488.

62. Harrus S, Waner T, Aizenberg I, Foley JE, Poland AM, Bark H. Amplification of ehrlichial DNA from dogs 34 months after infection with Ehrlichia canis. J Clin Microbiol. 1998;36:73-76.

63. Stricker RB, Maloney EL. Acute infection with human monocytic ehrlichiosis: the tip of the iceberg? South Med J. 2008;101:214-215.

64. Dumler JS, Bakken JS. Human granulocytic ehrlichiosis in Wisconsin and Minnesota: a frequent infection with the potential for persistence. J Infect Dis. 1996;173:1027-1030.

65. Grzeszczuk A, Puzanowska B, Miegoc H, Prokopowicz D. Incidence and prevalence of infection with Anaplasma phagocytophilum: prospective study in healthy individuals exposed to ticks. Ann Agric Environ Med. 2004;11:155-157.

66. Chomel BB, Kasten RW, Sykes JE, Boulouis HJ, Breitschwerdt EB. Clinical impact of persistent Bartonella bacteremia in humans and animals. Ann N Y Acad Sci. 2003;990:267-278.

67. Florin TA, Zaoutis TE, Zaoutis LB. Beyond cat scratch disease: widening spectrum of Bartonella henselae infection. Pediatrics. 2008;121:e1413-e1425.

68. Thomas V, Anguita J, Barthold SW, Fikrig E. Coinfection with Borrelia burgdorferi and the agent of human granulocytic ehrlichiosis alters murine immune responses, pathogen burden, and severity of Lyme arthritis. Infect Immun. 2001;69:3359-3371.

69. Zeidner NS, Dolan MC, Massung R, Piesman J, Fish D. Coinfection with Borrelia burgdorferi and the agent of human granulocytic ehrlichiosis suppresses IL-2 and IFN gamma production and promotes an IL-4 response in $\mathrm{C} 3 \mathrm{H} / \mathrm{HeJ}$ mice. Parasite Immunol. 2000;22:581-588.

70. Eskow E, Rao RV, Mordechai E. Concurrent infection of the central nervous system by Borrelia burgdorferi and Bartonella henselae: evidence for a novel tick-borne disease complex. Arch Neurol. 2001;58:1357-1363.

71. Moro MH, Zegarra-Moro OL, Bjornsson J, et al. Increased arthritis severity in mice coinfected with Borrelia burgdorferi and Babesia microti. J Infect Dis. 2002;186:428-431.

72. Krause PJ, Telford SR 3rd, Spielman A, et al. Concurrent Lyme disease and babesiosis. Evidence for increased severity and duration of illness. JAMA. 1996;275:1657-1660.

73. Oleson CV, Sivalingam JJ, O'Neill BJ, Staas WE. Transverse myelitis secondary to coexistent Lyme disease and babesiosis. J Spinal Cord Med. 2003;26:168-171.

74. Klieneberger E. The natural occurrence of pleuropneumonia like organisms in apparent symbiosis with Streptobacillus moniliformis and other bacteria. J Pathol Bacteriol. 1935;40:93-105.

75. Dienes L, Weinberger HJ. The L forms of bacteria. Bacteriol Rev. 1951; 15:245-288.

76. Domingue GJ, Woody HB. Bacterial persistence and expression of disease. Clin Microbiol Rev. 1997;10:320-344.

77. Margulis LJ, Ashen B, Sole M, Guerrero R. Composite, large spirochetes from microbial mats: spirochete structure review. Proc Natl Acad Sci U SA. 1993;90:6966-6970.

78. Preac Mursic V, Wanner G, Reinhardt S, Busch U, Marget W. Formation and cultivation of Borrelia burgdorferi spheroplast-L-form variants. Infection. 1996;24:218-226.

79. Brorson Ø, Brorson SH. Transformation of cystic forms of Borrelia burgdorferi to normal mobile spirochetes. Infection. 1997;25:240-246.

80. Brorson Ø, Brorson SH. In vitro conversion of Borrelia burgdorferi to cystic forms in spinal fluid, and transformation to mobile spirochetes by incubation in BSK-H medium. Infection. 1998;26:144-150.

81. Gruntar I, Malovrh T, Murgia R, Cinco M. Conversion of Borrelia garinii cystic forms to motile spirochetes in vivo. APMIS. 2001;109:383-388.

82. Murgia R, Cinco M. Induction of cystic forms by different stress conditions in Borrelia burgdorferi. APMIS. 2004;112:57-62.

83. de Oliveira A, Fonseca AH, da Costa CM, Mantovani E, Yoshinari NH. Growth, cysts and kinetics of Borrelia garinii (Spirochaetales: Spirochaetacea) in different culture media. Mem Inst Oswaldo Cruz. 2010;105:717-719. 
84. Miklossy J, Khalili K, Gern L, et al. Borrelia burgdorferi persists in the brain in chronic Lyme neuroborreliosis and may be associated with Alzheimer disease. J Alzheimers Dis. 2004;6:639-649.

85. MacDonald AB. Plaques of Alzheimer's disease originate from cysts of Borrelia burgdorferi, the Lyme disease spirochete. Med Hypotheses. 2006;67:592-600.

86. Miklossy J, Kasas S, Zurn AD, McCall S, Yu S, McGeer PL. Persisting atypical and cystic forms of Borrelia burgdorferi and local inflammation in Lyme neuroborreliosis. J Neuroinflammation. 2008;5:40.

87. Brorson $\varnothing$, Brorson SH. An in vitro study of the susceptibility of mobile and cystic forms of Borrelia burgdorferi to metronidazole. APMIS. 1999;107:566-576.

88. Brorson $\varnothing$, Brorson $\mathrm{SH}$. An in vitro study of the susceptibility of mobile and cystic forms of Borrelia burgdorferi to tinidazole. Int Microbol. 2004; 7:139-142.

89. Brorson $\varnothing$, Brorson SH. An in vitro study of the activity of telithromycin against mobile and cystic forms of Borrelia afzelii. Infection. 2006;34:26-28.

90. Brorson Ø, Brorson SH, Scythes J, MacAllister J, Wier A, Margulis L. Destruction of spirochete Borrelia burgdorferi round-body propagules (RBs) by the antibiotic tigecycline. Proc Natl Acad Sci U S A. 2009;106:18656-18661.

91. Glover WA, Yang Y, Zhang Y. Insights into the molecular basis of L-form formation and survival in Escherichia coli. PLoS One. 2009;4:e7316.

92. Davey ME, O’Toole GA. Microbial biofilms: from ecology to molecular genetics. Microbiol Mol Biol Rev. 2000;64:847-867.

93. Stoodley P, Sauer K, Davies DG, Costerton JW. Biofilms as complex differentiated communities. Annu Rev Microbiol. 2002;56:187-209.

94. Hoa M, Syamal M, Schaeffer MA, Sachdeva L, Berk R, Coticchia J. Biofilms and chronic otitis media: an initial exploration into the role of biofilms in the pathogenesis of chronic otitis media. Am JOtolaryngol. 2010;31:241-245.

95. Trautner BW, Darouiche RO. Role of biofilm in catheter-associated urinary tract infection. Am J Infect Control. 2004;32:177-183.

96. de Paz LE, Bergenholtz G, Svensäter G. The effects of antimicrobials on endodontic biofilm bacteria. J Endod. 2010;36:70-77.

97. Hamilton S, Bongaerts RJ, Mulholland F, et al. The transcriptional programme of Salmonella enterica serovar Typhimurium reveals a key role for tryptophan metabolism in biofilms. BMC Genomics. 2009;10:599.

98. Ramage G, Mowat E, Jones B, Williams C, Lopez-Ribot J. Our current understanding of fungal biofilms. Crit Rev Microbiol. 2009; 35:340-355.

99. Sapi E, MacDonald A. Biofilms of Borrelia burgdorferi in chronic cutaneous borreliosis. Am J Clin Pathol. 2008;129:988-989.

100. Dunham-Ems SM, Caimano MJ, Pal U, et al. Live imaging reveals a biphasic mode of dissemination of Borrelia burgdorferi within ticks. J Clin Invest. 2009;119:3652-3665.

101. Eisendle K, Müller H, Zelger B. Biofilms of Borrelia burgdorferi in chronic cutaneous borreliosis. Am J Clin Pathol. 2008;129:989-990.

102. Ryjenkov DA, Tarutina M, Moskvin OV, Gomelsky M. Cyclic diguanylate is a ubiquitous signaling molecule in bacteria: insights into biochemistry of the GGDEF protein domain. J Bacteriol. 2005;187: 1792-1798.

103. Cotter PA, Stibitz S. c-di-GMP-mediated regulation of virulence and biofilm formation. Curr Opin Microbiol. 2007;10:17-23.

104. Rogers EA, Terekhova D, Zhang HM, Hovis KM, Schwartz I, Marconi RT. Rrp1, a cyclic-di-GMP-producing response regulator, is an important regulator of Borrelia burgdorferi core cellular functions. Mol Microbiol. 2009;71:1551-1573.

105. Freedman JC, Rogers EA, Kostick JL, et al. Identification and molecular characterization of a cyclic-di-GMP effector protein, PlzA (BB0733): additional evidence for the existence of a functional cyclic-di-GMP regulatory network in the Lyme disease spirochete, Borrelia burgdorferi. FEMS Immunol Med Microbiol. 2010;58:285-294.

106. Sauer K. The genomics and proteomics of biofilm formation. Genome Biol. 2003;4:219.
107. Petrova OE, Sauer K. A novel signaling network essential for regulating Pseudomonas aeruginosa biofilm development. PLoS Pathog. 2009;5:e1000668.

108. Richards JJ, Melander C. Controlling bacterial biofilms. Chembiochem . 2009; 10:2287-2294.

109. Rogers SA, Huigens RW 3rd, Cavanagh J, Melander C. Synergistic effects between conventional antibiotics and 2-aminoimidazole-derived antibiofilm agents. Antimicrob Agents Chemother. 2010;54: 2112-2118

110. Stricker RB, Johnson L. Lyme wars: let's tackle the testing. BMJ. 2007;335:1008

111. Tilton RC, Sand MN, Manak M. The Western immunoblot for Lyme disease: determination of sensitivity, specificity, and interpretive criteria with use of commercially available performance panels. Clin Infect Dis. 1997;25(Suppl 1):S31-S34.

112. Binnicker MJ, Jespersen DJ, Harring JA, Rollins LO, Bryant SC, Beito EM. Evaluation of two commercial systems for the automated processing, reading and interpretation of Lyme Western blots. J Clin Microbiol. 2008;46:2216-2221.

113. Santino I, Berlutti F, Pantanella F, Sessa R, del Piano M. Detection of Borrelia burgdorferi sensu lato DNA by PCR in serum of patients with clinical symptoms of Lyme borreliosis. FEMS Microbiol Lett. 2008;283:30-35.

114. Stricker RB, Johnson L. Lyme disease debate: facts or fiction. BMJ Rapid Response. Available from: http://www.bmj.com/ content/335/7628/1008.1.full/reply - bmj_el_194233. Accessed Nov 82010.

115. Stricker RB. IDSA hearing presentation: Problems with diagnosis and treatment of Lyme disease. Available from: http://www.ilads.org/lyme_ disease/media/lyme_video_stricker.html. Accessed Nov 82010.

116. Stricker RB, Johnson L. Gender bias in chronic lyme disease. JWomens Health (Larchmt). 2009;18:1717-1718.

117. Sillanpää H, Lahdenne P, Sarvas H, et al. Immune responses to borrelial VlsE IR6 peptide variants. Int J Med Microbiol. 2007;297:45-52.

118. Gomes-Solecki MJ, Meirelles L, Glass J, Dattwyler RJ. Epitope length, genospecies dependency, and serum panel effect in the IR6 enzymelinked immunosorbent assay for detection of antibodies to Borrelia burgdorferi. Clin Vaccine Immunol. 2007;14:875-879.

119. Crowder CD, Matthews HE, Schutzer S, et al. Genotypic variation and mixtures of Lyme Borrelia in Ixodes ticks from North America and Europe. PLoS One. 2010;5:e10650.

120. Eshoo MW, Crowder CD, Li H, et al. Detection and identification of Ehrlichia species in blood by use of PCR and electrospray ionization mass spectrometry. J Clin Microbiol. 2010;48:472-478.

121. Stricker RB, Winger EE. Decreased CD57 lymphocyte subset in patients with chronic Lyme disease. Immunol Lett. 2001;76: 43-48.

122. Stricker RB, Burrascano J, Winger EE. Longterm decrease in the CD57 lymphocyte subset in a patient with chronic Lyme disease. Ann Agric Environ Med. 2002;9:111-113.

123. Stricker RB, Winger EE. Natural killer cells in chronic Lyme disease. Clin Vaccine Immunol. 2009;16:1704.

124. Shoemaker RC, Giclas PC, Crowder C, House D, Glovsky MM. Complement split products $\mathrm{C} 3 \mathrm{a}$ and $\mathrm{C} 4 \mathrm{a}$ are early markers of acute Lyme disease in tick bite patients in the United States. Int Arch Allergy Immunol. 2008;146:255-261.

125. Stricker RB, Savely VR, Motanya NC, Giclas PC. Complement split products C3a and C4a in chronic Lyme disease. Scand J Immunol. 2009;69:64-69.

126. Barbour AG, Jasinskas A, Kayala MA, et al. A genome-wide proteome array reveals a limited set of immunogens in natural infections of humans and white-footed mice with Borrelia burgdorferi. Infect Immun. 2008;76:3374-3389.

127. Xu Y, Bruno JF, Luft BJ. Profiling the humoral immune response to Borrelia burgdorferi infection with protein microarrays. Microb Pathog. 2008;45:403-407. 
128. Montagnier L, Aïssa J, Ferris S, Montagnier JL, Lavallée C. Electromagnetic signals are produced by aqueous nanostructures derived from bacterial DNA sequences. Interdiscip Sci. 2009;1:81-90.

129. Montagnier L, Aïssa J, Lavallée C, Mbamy M, Varon J, Chenal H. Electromagnetic detection of HIV DNA in the blood of AIDS patients treated by antiretroviral therapy. Interdiscip Sci. 2009;1:245-253.

130. Griffin MT. AIDS drugs and the pharmaceutical industry: a need for reform. Am J Law Med. 1991;17:363-410.

131. Stricker RB, Johnson L. Lyme disease diagnosis and treatment: lessons from the AIDS epidemic. Minerva Med. 2010;101:419-425.
132. Lawson $\mathrm{K}$. Treatment options and patient perspectives in the management of fibromyalgia: future trends. Neuropsychiatr Dis Treat. 2008;4: 1059-1071.

133. Stricker RB. Counterpoint: long-term antibiotic therapy improves persistent symptoms associated with Lyme disease. Clin Infect Dis. 2007;45:149-157.

134. Stricker RB, Johnson L. Chronic Lyme disease and the 'Axis of Evil'. Future Microbiol. 2008;3:621-624.

\section{Appendix}

Appendix I Evidence for persistent infection following treatment of Lyme disease ${ }^{\text {a }}$

\begin{tabular}{|c|c|c|c|}
\hline Study/reference & Study origin & $\begin{array}{l}\text { Persistence of B. burgdorferi } \\
\text { shown by }\end{array}$ & Sample source \\
\hline Weber et al' & Europe & Histology & Brain, liver (autopsy) \\
\hline Schmidli et $\mathrm{al}^{2}$ & Europe & Culture & Synovial fluid \\
\hline Cimmino et $\mathrm{al}^{3}$ & Europe & Histology & Spleen \\
\hline Preac-Mursic et $\mathrm{al}^{4}$ & Europe & Culture & Skin Bx, CSF \\
\hline Pfister et al ${ }^{5}$ & Europe & Culture & CSF \\
\hline Strle et $\mathrm{al}^{6}$ & Europe & Culture & Skin Bx \\
\hline Preac-Mursic et al ${ }^{7}$ & Europe & Culture & Iris $B x$ \\
\hline Haupl et $\mathrm{a}^{8}$ & Europe & Culture & Ligament Bx \\
\hline Strle et $\mathrm{al}^{9}$ & Europe & Culture & Skin Bx \\
\hline Preac-Mursic et al ${ }^{10}$ & Europe & Culture & Skin Bx, CSF \\
\hline \multirow[t]{3}{*}{ Oksi et al" } & Europe & Culture & CSF \\
\hline & & PCR & Brain Bx \\
\hline & & PCR & Brain (autopsy) \\
\hline Priem et $\mathrm{al}^{12}$ & Europe & PCR & Synovial Bx/fluid \\
\hline Oksi et $\mathrm{al}^{13}$ & Europe & Culture, PCR & Blood \\
\hline Breier et al ${ }^{14}$ & Europe & Culture & Skin Bx \\
\hline Hunfeld et al ${ }^{15}$ & Europe & Culture & Skin Bx \\
\hline Hudson et $\mathrm{al}^{16}$ & Australia & Culture, PCR & Skin Bx \\
\hline Steere et a $\mathrm{al}^{17}$ & USA & Histology & Synovial Bx \\
\hline Kirsch et $\mathrm{al}^{18}$ & USA & Histology & LN (autopsy) \\
\hline \multirow[t]{2}{*}{ Liegner et a $\left.\right|^{19}$} & USA & Histology & Skin Bx \\
\hline & & PCR & Blood \\
\hline Battafarano et $\mathrm{al}^{20}$ & USA & Histology, PCR & Synovial Bx/fluid \\
\hline Chancellor et $\mathrm{al}^{21}$ & USA & Histology & Bladder Bx \\
\hline Nocton et $\mathrm{a}^{22}$ & USA & PCR & Synovial fluid \\
\hline Shadick et $\mathrm{al}^{23}$ & USA & Histology & Brain (autopsy) \\
\hline Masters ${ }^{24}$ & USA & Culture & Blood \\
\hline Lawrence et $\mathrm{a}^{25}$ & USA & PCR & CSF \\
\hline Bayer et $\mathrm{a}^{26}$ & USA & PCR & Urine \\
\hline Nocton et $\mathrm{al}^{27}$ & USA & PCR & CSF \\
\hline
\end{tabular}

Notes: ${ }^{a}$ All patients had received a minimum of 2 to 4 weeks of antibiotic therapy; ${ }^{b}$ Mother treated with antibiotics during pregnancy; newborn died.

Abbreviations: PCR, polymerase chain reaction; Bx, biopsy; CSF, cerebrospinal fluid; LN, lymph node.

\section{References}

1. Weber K, Bratzke HJ, Neubert U, Wilske B, Duray PH. Borrelia burgdorferi in a newborn despite oral penicillin for Lyme borreliosis during pregnancy. Pediatr Infect Dis J. 1988;7:286-289.

2. Schmidli J, Hunziker T, Moesli P, Schaad UB. Cultivation of Borrelia burgdorferi from joint fluid three months after treatment of facial palsy due to Lyme borreliosis. J Infect Dis. 1988;158:905-906.

3. Cimmino MA, Azzolini A, Tobia F, Pesce CM. Spirochetes in the spleen of a patient with chronic Lyme disease. Am J Clin Pathol. 1989;91: 95-97.

4. Preac-Mursic V, Weber K, Pfister HW, et al. Survival of Borrelia burgdorferi in antibiotically treated patients with Lyme borreliosis. Infection. 1989;17:355-359.
5. Pfister HW, Preac-Mursic V, Wilske B, Schielke E, Sorgel F, Einhaupl KMJ. Randomized comparison of ceftriaxone and cefotaxime in Lyme neuroborreliosis. Infect Dis. 1991;163:311-318.

6. Strle F, Preac-Mursic V, Cimperman J, Ruzic E, Maraspin V, Jereb M. Azithromycin versus doxycycline for treatment of erythema migrans: clinical and microbiological findings. Infection. 1993;21:83-88.

7. Preac-Mursic V, Pfister HW, Spiegel H, et al. First isolation of Borrelia burgdorferi from an iris biopsy. J Clin Neuroophthalmol. 1993;13: 155-161.

8. Haupl T, Hahn G, Rittig M, et al. Persistence of Borrelia burgdorferi in ligamentous tissue from a patient with chronic Lyme borreliosis. Arthritis Rheum. 1993;36:1621-1626. 
9. Strle F, Maraspin V, Lotric-Furlan S, Ruziç-Sabljiç E, Cimperman J. Azithromycin and doxycycline for treatment of Borrelia culture-positive erythema migrans. Infection. 1996;24:64-68.

10. Preac-Mursic V, Marget W, Busch U, Pleterski Rigler D, Hagl S. Kill kinetics of Borrelia burgdorferi and bacterial findings in relation to the treatment of Lyme borreliosis. Infection. 1996;24:9-16.

11. Oksi J, Kalimo H, Marttila RJ, et al. Inflammatory brain changes in Lyme borreliosis. A report on three patients and review of literature. Brain. 1996;119:2143-2154.

12. Priem S, Burmester GR, Kamradt T, Wolbart K, Rittig MG, Krause A. Detection of Borrelia burgdorferi by polymerase chain reaction in synovial membrane, but not in synovial fluid from patients with persisting Lyme arthritis after antibiotic therapy. Ann Rheum Dis. 1998;57: $118-121$.

13. Oksi J, Marjamaki M, Nikoskelainen J, Viljanen MK. Borrelia burgdorferi detected by culture and PCR in clinical relapse of disseminated Lyme borreliosis. Ann Med. 1999;31:225-232.

14. Breier F, Khanakah G, Stanek G, et al. Isolation and polymerase chain reaction typing of Borrelia afzelii from a skin lesion in a seronegative patient with generalized ulcerating bullous lichen sclerosus et atrophicus. Br J Dermatol. 2001;144:387-392.

15. Hunfeld KP, Ruzic-Sabljic E, Norris DE, Kraiczy P, Strle F. In vitro susceptibility testing of Borrelia burgdorferi sensu lato isolates cultured from patients with erythema migrans before and after antimicrobial chemotherapy. Antimicrob Agents Chemother. 2005;49:1294-1301.

16. Hudson BJ, Stewart M, Lennox VA, et al. Culture-positive Lyme borreliosis. Med J Aust. 1998;168:500-502.

17. Steere AC, Duray PH, Butcher EC. Spirochetal antigens and lymphoid cell surface markers in Lyme synovitis. Comparison with rheumatoid synovium and tonsillar lymphoid tissue. Arthritis Rheum. 1988;31:487-495.
18. Kirsch M, Ruben FL, Steere AC, Duray PH, Norden CW, Winkelstein A Fatal adult respiratory distress syndrome in a patient with Lyme disease. JAMA. 1988;259:2737-2739.

19. Liegner KB, Shapiro JR, Ramsay D, Halperin AJ, Hogrefe W, Kong L. Recurrent erythema migrans despite extended antibiotic treatment with minocycline in a patient with persisting Borrelia burgdorferi infection. J Am Acad Dermatol. 1993;28(2 pt 2):312-314.

20. Battafarano DF, Combs JA, Enzenauer RJ, Fitzpatrick JE. Chronic septic arthritis caused by Borrelia burgdorferi. Clin Orthop. 1993;297: 238-241.

21. Chancellor MB, McGinnis DE, Shenot PJ, Kiilholma P, Hirsch IH. Urinary dysfunction in Lyme disease. J Urol. 1993;149:26-30.

22. Nocton JJ, Dressler F, Rutledge BJ, Rys PN, Persing DH, Steere AC. Detection of Borrelia burgdorferi DNA by polymerase chain reaction in synovial fluid from patients with Lyme arthritis. N Engl J Med. 1994; 330:229-234.

23. Shadick NA, Phillips CB, Logigian EL, et al. The long-term clinical outcomes of Lyme disease. A population-based retrospective cohort study. Ann Intern Med. 1994;121:560-567.

24. Masters E. Spirochetemia after continuous high-dose oral amoxicillin therapy. Infect Dis Clin Prac. 1994;3:207-208.

25. Lawrence C, Lipton RB, Lowy FD, Coyle PK. Seronegative chronic relapsing neuroborreliosis. Eur Neurol. 1995;35:113-117.

26. Bayer ME, Zhang L, Bayer MH. Borrelia burgdorferi DNA in the urine of treated patients with chronic Lyme disease symptoms. A PCR study of 97 cases. Infection. 1996;24:347-353.

27. Nocton JJ, Bloom BJ, Rutledge BJ. Detection of Borrelia burgdorferi DNA by polymerase chain reaction in cerebrospinal fluid in Lyme neuroborreliosis. J Infect Dis. 1996;174:623-627.
Infection and Drug Resistance

\section{Publish your work in this journal}

Infection and Drug Resistance is an international, peer-reviewed openaccess journal that focuses on the optimal treatment of infection (bacterial, fungal and viral) and the development and institution of preventive strategies to minimize the development and spread of resistance. The journal is specifically concerned with the epidemiology of antibiotic

\section{Dovepress}

resistance and the mechanisms of resistance development and diffusion in both hospitals and the community. The manuscript management system is completely online and includes a very quick and fair peerreview system, which is all easy to use. Visit http://www.dovepress.com/ testimonials.php to read real quotes from published authors. 